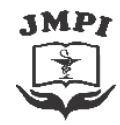

Jurnal Mandala Pharmacon Indonesia, Vol 7.No.1 Juni 2021

Avaiable online at www.jurnal-pharmaconmw.com/jmpi

p-ISSN : 2442-6032

e-ISSN : 2598-9979

\title{
Review : Imunoterapi Penanganan Infeksi Virus
}

\author{
Usmar $^{1}$, Andi Maqhfirah Nurul Fitri ${ }^{1}$, Dewi Yuliana ${ }^{2}$, Firzan Nainu ${ }^{1 *}$ \\ 1Fakultas Farmasi, Universitas Hasanuddin, Makassar \\ 2Fakultas Farmasi, Universitas Muslim Indonesia, Makassar
}

\begin{abstract}
ABSTRAK
Penyakit menular akibat virus merupakan salah satu masalah kesehatan global yang mempengaruhi sistem kesehatan masyarakat dan ekonomi di seluruh dunia. Hal tersebut mendorong disusunnya artikel ini untuk mendiskusikan relevansi dan pentingnya imunoterapi dalam menentukan pilihan terapetik terkait infeksi virus, dengan menitikberatkan pembahasan pada ketersediaan pilihan vaksin dan obat yang telah ditemukan untuk membantu manusia melawan berbagai jenis infeksi yang disebabkan oleh virus. Penulisan artikel review naratif ini dilakukan menggunakan metode analisis pustaka primer maupun sekunder terkait yang berhasil dikumpulkan dari database online Google Scholar dan NCBI-PubMed. Selain itu, sumber acuan pustaka juga diambil dari beberapa buku teks akademik. Imunoterapi merupakan bidang yang berkembang melalui interaksi bidang imunologi, farmakologi dan farmakoterapi yang memiliki
\end{abstract}

perkembangan yang pesat terutama dalam kondisi pandemi COVID-19 yang dihadapi saat ini. Meskipun terapi dan obat-obatan yang digunakan dalam bidang imunofarmakologi masih terbatas serta banyak hal yang belum dapat ditemukan, namun teknologi baru dan kemajuan pesat dalam pengetahuan tentang regulasi sistem imun telah menjadikan imunoterapi sebagai bidang yang memiliki potensi besar dan menjanjikan dalam penanganan infeksi virus maupun patogen lain. Oleh karena itu, konsep imunoterapi serta relevansinya dengan penyakit manusia merupakan salah satu solusi yang menawarkan pilihan baru untuk kebutuhan medis yang belum terpenuhi terkait penyakit infeksi akibat virus.

Kata Kunci: COVID-19, imunofarmakologi, imunoterapi, infeksi virus, imunitas

\section{ABSTRACT}

Viral infectious disease is a global health problem that affects public health systems and economies worldwide. Such reason prompts the preparation of this article to discuss the relevance and importance of immunotherapy in determining therapeutic options related to viral infections, focusing on the availability of vaccines and drugs that have been found to help humans to fight various types of infections caused by viruses. The writing of this narrative review article was carried out using the related primary and secondary literature analysis methods that were collected from the online databases of Google Scholar and NCBI-PubMed. In addition, reference sources are also taken from several academic textbooks. Immunotherapy is a field that is developing through the interaction of the fields of immunology, pharmacology and pharmacotherapy which has rapid development, especially in the current state of the COVID-19 pandemic. Although therapies and drugs used in the field of immunopharmacology are still limited and many things have not yet been discovered, new technologies and rapid advances in knowledge about the regulation of the immune system have made immunotherapy a field that has great and promising potential in the treatment of viral and other pathogenic infections. Therefore, the concept of immunotherapy and its relevance to human disease is one solution that offers new options for medical needs that have not been met related to viral infectious diseases.

Keywords: COVID-19, immunopharmacology, immunotherapy, viral infections, immunity
Penulis Korespondensi :

Firzan Nainu

Fakultas Farmasi, Universitas Hasanuddin,

E-mail : firzannainu@gmail.com
Informasi Artikel

Submitted : 14 Juni 2021

Accepted : 23 Juni 2021

Published : : 30 Juni 2021 


\section{PENDAHULUAN}

Dalam beberapa dekade terakhir, penyakit menular akibat virus merupakan salah satu masalah kesehatan global yang mempengaruhi sistem kesehatan masyarakat dan ekonomi di seluruh dunia (Graham and Sullivan, 2018, Riley and Blanton, 2018). Infeksi virus dapat terjadi kapan saja dan tidak terbatas pada umur, ras, maupun jenis kelamin tertentu (Riley and Blanton, 2018). Sebagai parasit intraseluler, virus dapat menginvasi berbagai organ pada tubuh manusia maupun spesies lainnya, mengakibatkan berbagai jenis penyakit, dari ringan hingga parah. Misalnya, infeksi oleh empat jenis human coronavirus (229E, NL63, OC43, and HKU1) yang dapat menyebabkan infeksi ringan hingga sedang pada saluran pernapasan (Zumla et al., 2016), infeksi herpes simplex virus 1 dan 2 (HSV-1 dan HSV-2) pada bagian kulit (Whitley and Roizman, 2001) hingga infeksi pada organ-organ tubuh bagian dalam oleh virus hepatitis dan HIV yang hingga kini masih menjadi ancaman global (Deeks et al., 2015, Yuen et al., 2018). Bahkan, sejak akhir 2019 hingga sekarang, penduduk dunia masih terancam dengan keberadaan SARS-CoV-2, coronavirus jenis baru yang menyebabkan pandemi COVID-19 (Harapan et al., 2020).

Infeksi virus didefinisikan sebagai penyakit yang disebabkan oleh patogen berupa virus yang timbul melalui penularan dari orang yang terinfeksi, hewan yang terinfeksi, atau benda mati yang terkontaminasi ke inang yang rentan (Usmar et al., 2017). Secara umum, pengendalian penyakit menular akibat virus telah mulai mengalami kemajuan. Hal ini tercapai melalui peningkatan kepedulian masyarakat global dalam aspek sanitasi, peningkatan kualitas perawatan medis, dan maraknya pengembangan vaksin dan antivirus baru dari berbagai sumber hayati sebagai salah satu upaya imunofarmakologi dan imunoterapi (Graham and Sullivan, 2018, Verhoef et al., 2019).

Mekanisme pertahanan tubuh terhadap infeksi virus dapat dibagi menjadi respons imun alamiah (bawaan) dan respons imun adaptif (dapatan). Respons imun alamiah merupakan respons awal terhadap infeksi, tidak spesifik untuk patogen, dan tidak membuat organisme resisten terhadap infeksi berikutnya oleh patogen yang sama (Murphy and Weaver, 2016). Sebaliknya, respons imun adaptif membutuhkan waktu untuk berkembang, spesifik untuk patogen yang menyerang, dan diikuti oleh memori imunologis sehingga bila terjadi paparan yang sama, maka akan menghasilkan respon yang lebih cepat untuk melawan dan menghancurkan patogen tersebut (Murphy and Weaver, 2016). Respons imun alamiah dan adaptif tidak berfungsi secara independen satu sama lain dan sistem imun yang memadai membutuhkan aktivitas keduanya. 
Konsekuensi dari tidak memadainya sistem imun pada tubuh diilustrasikan dengan baik oleh pengamatan pada tubuh bayi baru lahir yang sangat rentan terhadap infeksi virus maupun mikroba sebab imunitas adaptifnya belum pernah terpapar sebelumnya. Hal ini memberikan perbedaan yang signifikan jika dibandingkan dengan orang dewasa (Murphy and Weaver, 2016, Yu et al., 2018).

Salah satu langkah yang dapat dilakukan untuk menangani infeksi virus adalah melalui pendekatan imunofarmakologi dan imunoterapi. Dalam studi imunofarmakologi, modulasi respon imun dipelajari dan dianalisis melalui regulasi inhibisi maupun induksi terhadap aktivitas sel dan jaringan, baik dari sistem imun alamiah maupun sistem imun adaptif dengan tujuan untuk mendapatkan pilihan terapeutik yang lebih efektif dan lebih aman bagi pasien. Saat ini, imunofarmakologi dan imunoterapi dipandang penting untuk memenuhi kebutuhan klinis berbagai kondisi patologis seperti penyakit autoimun, alergi dan asma, imunodefisiensi, infeksi kronis, tumor, penyakit inflamasi dan degeneratif kronis, hingga gangguan metabolisme (Harding et al., 2018, Khan, 2016, Rouse and Sehrawat, 2010, Verhoef et al., 2019). Dalam artikel review ini, kami akan mendiskusikan mengenai relevansi dan pentingnya imunoterapi dalam menentukan pilihan terapetik terkait infeksi virus, dengan menitikberatkan pembahasan pada ketersediaan pilihan vaksin dan obat yang telah ditemukan untuk membantu manusia melawan berbagai jenis infeksi yang disebabkan oleh berbagai jenis virus.

\section{METODE PENELITIAN}

Penulisan artikel review naratif ini dilakukan menggunakan metode analisis pustaka primer maupun sekunder dalam rentang waktu terbitan 2000-2021 yang berhasil dikumpulkan dari database online Google Scholar dan NCBI-PubMed. Selain itu, sumber acuan pustaka juga diambil dari beberapa buku teks akademik. Kata kunci yang digunakan dalam penelusuran pustaka adalah "immunopharmacology, "immunotherapy ", "viral infection", "immunity", "pharmacology of viral infection", "imunofarmakologi”,"imunoter api”, “infeksi virus”, “imunitas”, dan "farmakologi infeksi virus". Literatur yang terkumpul kemudian diklasifikasikan dan ditelaah serta disusun menjadi sebuah review naratif berdasarkan format yang ditentukan.

\section{HASIL DAN PEMBAHASAN}

Virus adalah patogen subseluler dan merupakan parasit obligat intraseluler yang menginfeksi dan mengambil alih fungsi komponen 
sitoplasma sel inang untuk bereplikasi (Fields et al., 2013). Secara umum, virus diselubungi oleh pelindung yang terdiri atas protein, lipid, glikopropein, atau kombinasi ketiganya, yang disebut kapsid, serta mengandung genom asam nukleat DNA atau RNA (Fields et al., 2013). Sebagai parasit obligat intraseluler, virus sangat bergantung pada komponenkomponen biokimia sel eukariotik maupun prokariotik untuk menunjang proses replikasinya. Setelah berhasil masuk ke dalam sel, virus akan mengirimkan genomnya ke dalam sel inang untuk selanjutnya diekspresikan (transkripsi dan translasi) oleh sel inang untuk menjadi protein fungsional yang kemudian akan mendukung proses replikasi virus membentuk virion baru (Fields et al., 2013, Wagner et al., 2007).

Partikel lengkap virus disebut virion. Genom yang dikandung oleh virion akan dibawa ke sel inang untuk diekspresikan sehingga virion umumnya berfungsi sebagai alat transportasi gen (Fields et al., 2013). Virion paling sederhana terdiri dari dua komponen dasar, yaitu: asam nukleat (RNA atau DNA beruntai tunggal atau ganda) dan komponen struktural penyusun lainnya seperti selubung (envelope) protein dan kapsid atau nukleokapsid yang berfungsi sebagai cangkang untuk melindungi genom virus dari ancaman lingkungan ekstraseluler (Fields et al., 2013, Wagner et al., 2007). Selubung ini pula yang bertanggung jawab dalam mekanisme infeksi sel inang oleh virus. Melalui interaksi ligan tertentu pada selubung virus dengan reseptor spesifik pada sel inang, virus akan melekatkan diri pada sel inang dan menembus membrane sel (Fields et al., 2013, Wagner et al., 2007). Selain selubung, terdapat pula protein kapsid yang sangat penting bagi virus. Protein penyusun kapsid disandi oleh genom virus. Karena ukuran genom yang kecil dan kapasitas pengkodeannya yang terbatas, hanya beberapa protein struktural yang dapat dikode oleh genom sehingga diperlukan sejumlah salinan protein untuk membentuk struktur kapsid tiga dimensi. Perakitan kapsid virus mengikuti dua pola dasar yaitu simetri heliks dan simetri ikosahedral (Fields et al., 2013, Wagner et al., 2007).

Walaupun memiliki bentuk dan ukuran yang beragam, virus memiliki komponen asam nukleat yang sederhana, hanya berupa DNA atau RNA (Wagner et al., 2007). Inilah yang kemudian digunakan menjadi dasar klasifikasi virus menurut sistem yang diusulkan oleh David Baltimore (Fields et al., 2013, Wagner et al., 2007). Klasifikasi Baltimore mengelompokkan virus ke dalam tujuh kategori (Gambar 1) berdasarkan jenis asam nukleat yang dimiliki, yaitu: virus DNA beruntai ganda (Grup I), virus DNA untai tunggal (Grup II), virus RNA untai ganda (Grup III), virus RNA untai tunggal positif (Grup IV), virus RNA untai tunggal 
negatif (Grup V), virus RNA untai tunggal positif dengan zat antara DNA (Grup VI), dan retrovirus DNA untai ganda (Grup VII). Walaupun demikian, model yang paling populer dalam klasifikasi virus adalah yang diusulkan oleh Komite Internasional Taksonomi Virus (International Committee on Taxonomy of Viruses, ICTV) (Gorbalenya et al., 2020).

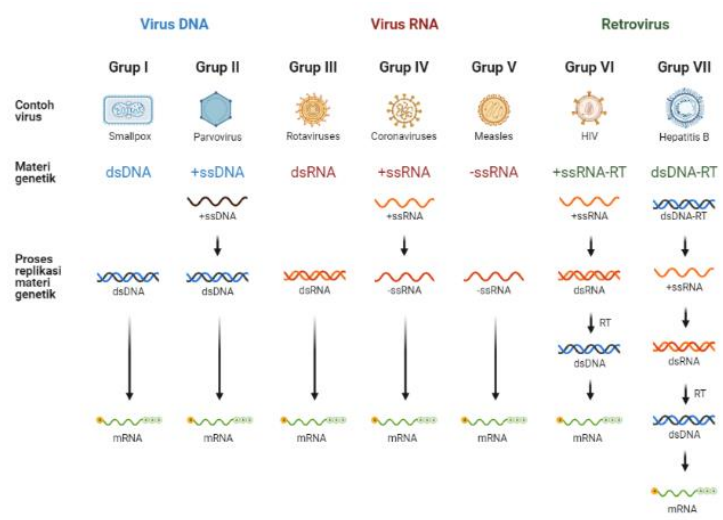

Gambar 1. Klasifikasi virus berdasarkan komponen asam nukleat dan mekanisme pembentukan RNA duta (messenger RNA, $m R N A$ ) menurut Baltimore classification system

\section{Replikasi virus dalam sel inang}

Replikasi virus berawal dari interaksi antara virus dengan reseptor virus yang diekspresikan pada permukaan sel inang, diikuti dengan penetrasi genom ke dalam sitoplasma (Wagner et al., 2007). Reseptor virus dapat berupa protein, seperti glikoprotein, atau residu karbohidrat yang terdapat pada glikoprotein atau glikolipid. Ketersediaan reseptor pada permukaan sel inang adalah penentu utama tropisme virus (Fields et al., 2013, Wagner et al., 2007). Setiap virus memiliki reseptor spesifik dan dalam beberapa kasus, virus yang berbeda dapat memiliki reseptor yang sama. Misalnya, virus Coxsackie B (Picornaviridae, virus RNA), dan adenovirus (Adenoviridae, virus DNA), menggunakan reseptor yang sama yaitu protein CAR (Coxsackieadenovirus receptor), anggota dari superfamili imunoglobulin

(Rossmann et al., 2002, Sharma et al., 2009). Contoh lain adalah asam sialat, karbohidrat yang melekat pada sebagian besar glikoprotein, digunakan oleh virus influenza (famili Orthomyxoviridae), human coronavirus $\mathrm{OC}_{3}$ (famili Coronaviridae), reovirus (Reoviridae), parvovirus sapi (Parvoviridae), dan banyak virus lainnya (Matrosovich et al., 2015). Sebaliknya, anggota keluarga virus yang sama mungkin menggunakan reseptor yang sangat berbeda seperti virus-virus jenis retrovirus (famili Retroviridae) dan virus-virus yang berada dalam family Coronaviridae (Dimitrov, 2004, Fields et al., 2013, Grove and Marsh, 2011).

Interaksi antara virus dengan reseptor bervariasi sesuai dengan jumlah dan jenis protein yang terlibat dalam proses tersebut. Beberapa virus kompleks seperti Poxviridae dan Herpesviridae dapat menggunakan lebih dari satu reseptor primer yang berfungsi sebagai reseptor alternatif (McFadden, 2005, Taylor et al., 2007). Beberapa virus juga 
mampu berikatan dengan reseptor aksesori, yang berafinitas rendah, sebelum ditransfer ke reseptor berafinitas tinggi di mana virus memasuki sel. Selain itu, beberapa virus juga berinteraksi dengan reseptor sekunder (koreseptor) selain interaksinya dengan reseptor primer (Maginnis, 2018). Contoh virus yang menggunakan koreseptor adalah HIV, yang menggunakan molekul permukaan sel, antigen sel-T, yang disebut $\mathrm{CD}_{4}$ sebagai reseptor primer dan kemokin CC sebagai koreseptor (Wilen et al., 2012).

Proses masuknya partikel atau genom virus ke dalam sitoplasma sel inang yang terjadi setelah virus berikatan dengan reseptor disebut sebagai proses penetrasi (Fields et al., 2013, Wagner et al., 2007). Untuk virus yang memiliki selubung, dapat menggunakan mode penetrasi berupa fusi langsung (menembus ke dalam sitosol langsung melalui membran plasma) atau melalui endositosis yang dimediasi oleh reseptor. Sedangkan, virus tanpa selubung hanya bisa berpenetrasi ke dalam sel inang melalui proses endositosis yang dimediasi reseptor (Dimitrov, 2004, Wagner et al., 2007). Beberapa virus, seperti virus Epstein-Barr, melakukan fusi langsung, di mana selubung virus dan membran sel berfusi dan nukleokapsid virus langsung dikirim ke sitoplasma, meninggalkan selubung virus di belakang membran plasma (Dimitrov, 2004, Helenius, 2018).
Namun, sebagian besar virus melakukan proses penetrasi ke sel inang melalui endositosis yang dimediasi oleh reseptor (Dimitrov, 2004, Helenius, 2018). Setelah pengikatan virus oleh reseptor, kompleks reseptor memicu pembentukan vesikel yang dimediasi oleh protein clathrin. Kompleks ini memicu endositosis, sehingga disebut clathrin-mediated endocytosis, yang pada akhirnya membentuk endosome berisi partikel virus. Endosom ini selanjutnya akan dipecah untuk menembus sitoplasma. Untuk virus yang memiliki selubung, kerusakan endosom dipicu oleh fusi membran antara selubung virus dan membran endosom. Untuk virus yang tidak berselubung, lisis endosom diinduksi oleh salah satu protein kapsid (Fields et al., 2013, Wagner et al., 2007).

Strategi replikasi genom virus berbeda satu sama lain, tergantung dari jenis komponen asam nukleat yang dimiliki. Terdapat tiga grup besar virus yang dapat dikenali, yaitu kelas pertama dan kedua adalah virus yang mengandung DNA atau RNA sebagai genom dengan masing-masing dapat berupa untai tunggal maupun untai ganda, serta kelas ketiga adalah virus yang memiliki gen pengkode enzim reverse transcriptase (Fields et al., 2013, Wagner et al., 2007). Virus grup pertama mengandung DNA sebagai genom, baik untai tunggal maupun untai ganda. Genom DNA 
direplikasi melalui penyalinan langsung DNA menjadi DNA, melalui bantuan enzim DNA polimerase. Virus DNA yang lebih kecil menggunakan DNA polimerase sel inang sedangkan virus DNA yang lebih besar umumnya memiliki DNA polimerase mereka sendiri (Fields et al., 2013). Virus DNA yang menggunakan DNA polimerase sel inang harus mereplikasi genomnya di dalam nukleus. Meskipun beberapa virus seperti adenovirus dan herpesvirus mampu menghasilkan DNA polimerase mereka sendiri (Hoeben and Uil, 2013, Weller and Coen, 2012), tetapi virus-virus tersebut juga mereplikasi genomnya di dalam nukleus sebab tidak menyandikan DNAdependent RNA polymerase (DdRP). Berbeda halnya dengan poxvirus yang mampu memproduksi DNA dan RNA polimerase (Kates and McAuslan, 1967) sehingga proses replikasi dan penyalinan genom poxvirus terjadi di sitoplasma (Fields et al., 2013).

Virus grup kedua mengandung RNA sebagai genomnya, baik untai tunggal maupun untai ganda. Genom RNA direplikasi melalui penyalinan langsung RNA menjadi RNA menggunakan RNAdependent RNA polymerase (RdRP) (Fields et al., 2013, Wagner et al., 2007). Virus RNA dibagi menjadi beberapa subkelompok, yaitu virus dengan genom RNA untai tunggal positif (single strand, positive sense), virus dengan genom RNA untai tunggal negatif (single strand, negative sense), dan virus dengan RNA untai ganda (double strand) (Fields et al., 2013, Wagner et al., 2007).

Virus grup ketiga menggunakan enzim reverse transcriptase (RT) dalam replikasi genomnya serta memiliki tahapan pengubahan RNA menjadi DNA dalam siklus hidupnya (Wagner et al., 2007). Terdapat dua famili virus yang menginfeksi vertebrata yang menggunakan enzim RT dalam replikasi genom mereka, yaitu retroviridae (misalnya HIV) dan hepadnaviridae (misalnya virus hepatitis B) (Fields et al., 2013). Pada retrovirus, enzim RT yang disandi di dalam genom virus akan diekspresikan untuk mengubah genom RNA retrovirus menjadi DNA untai ganda (double strand). Di dalam inti sel yang terinfeksi, RNA polimerase seluler mentranskripsi salinan DNA dari genom retrovirus untuk menghasilkan RNA yang akan ditranskripsikan secara terbalik. Secara sederhana, retrovirus mengikuti aturan $\mathrm{RNA} \rightarrow \mathrm{DNA} \rightarrow \mathrm{RNA}$. Retrovirus kemudian akan mengemas RNA ini ke dalam virion. Dengan demikian, replikasi genom retrovirus akan membentuk DNA intermediat (Fields et al., 2013, Wagner et al., 2007). Pada Hepadnaviridae, enzim RT yang disandi di dalam genom virus akan mengubah salinan RNA dari genom DNA hepadnavirus, menjadi DNA untai ganda. Di dalam inti sel yang terinfeksi, 
RNA polimerase seluler mentranskripsi genom DNA hepadnavirus untuk menghasilkan RNA yang akan ditranskripsikan secara terbalik. Hepadnavirus membalikkan transkripsi RNA menjadi DNA selama pengemasan, sehingga virion mengandung DNA. Dengan demikian, replikasi genom hepadnavirus akan membentuk RNA intermediat, sehingga dapat digambarkan mengikuti kaidah replikasi DNA $\rightarrow$ RNA $\rightarrow$ DNA (Fields et al., 2013, Wagner et al., 2007).

Setelah genom virus direplikasi dan protein-protein virus diekspresikan, selanjutnya adalah proses perakitan komponen virion. Perakitan kapsid mengikuti stuktur genom virus dan dapat dibagi menjadi dua proses yaitu perakitan kapsid dan pengemasan genom. Kedua proses ini dapat terjadi secara berurutan seperti pada picornavirus atau bersamaan dengan cara berpasangan seperti pada adenovirus (Li et al., 2012, San Martín, 2012). Pada picornavirus, prokapsid atau kapsid yang belum matang dirakit terlebih dahulu tanpa genom RNA. Selanjutnya genom RNA dikemas atau disisipkan melalui pori yang terbentuk pada struktur prokapsid (Li et al., 2012). Sebaliknya, perakitan kapsid digabungkan dengan pengemasan genom pada adenovirus (San Martín, 2012). Selanjutnya, proses maturasi atau pematangan virion akan dilaksanakan (Fields et al., 2013, Wagner et al., 2007). Enzim yang banyak terlibat dalam proses ini adalah protease atau enzim khusus yang disandi di dalam genom virus atau dapat pula keduanya (Fields et al., 2013, Wagner et al., 2007).

Fase terakhir dari pembentukan virion adalah fase pelepasan virion dari sel yang terinfeksi. Untuk virus yang tidak memiliki selubung atau tidak terlindungi, proses pelepasannya dari sel inang adalah melalui lisis sel inang (Fields et al., 2013). Lisis dapat terjadi sebagai respon terhadap gangguan seluler fungsi sel inang (akibat replikasi yang dilakukan oleh virus) atau dapat juga melalui induksi apoptosis oleh protein khusus yang diproduksi oleh virus, misalnya seperti pada polyomavirus SV4O (Bhat et al., 2020) dan adenovirus (Braithwaite and Russell, 2001). Sedangkan, virus yang memiliki selubung memperoleh membran lipidnya saat virus keluar dari sel melalui membran sel, atau pada saat virus keluar ke vesikel intraseluler sebelum pelepasan (Wagner et al., 2007). Protein selubung virus diambil selama proses ini yaitu pada saat partikel virus diekstrusi. Proses ini dikenal dengan istilah budding (Fields et al., 2013). Sebelum dilepaskan, virus yang memiliki selubung akan mengalami proses pembalutan atau envelopment, yaitu kapsid dikelilingi oleh lipid bilayer. Ada dua mekanisme yang dapat terjadi berkaitan dengan proses perakitan kapsid dan envelopment. Yang pertama, 
envelopment dilakukan setelah perakitan kapsid selesai, seperti pada replikasi virus herpes dan hepatitis B (Ryu, 2017) dan kapsid yang sudah tersusun lengkap akan direkrut ke membran melalui interaksi antara kapsid virus dengan glikoprotein pada amplop virus. Mekanisme lainnya yaitu proses envelopment dan kapsid dapat terjadi secara bersamaan seperti pada replikasi retrovirus (Ryu, 2017). Pada umumnya, virus yang memiliki selubung dilepaskan secara ekstraseluler melalui proses eksositosis (Ryu, 2017).

\section{Peran sistem imun dalam melawan infeksi virus}

Makhluk hidup memiliki komponen seluler dan humoral sistem imun yang bertugas mempertahankan tubuh manusia dari serangan patogen dan benda-benda asing lainnya (Murphy and Weaver, 2016). Komponen seluler dari sistem imun alamiah termasuk sel dendritik penyaji antigen, makrofag fagositik dan granulosit, sel pembunuh alami sitotoksik (Natural killer, NK), dan limfosit $\mathrm{T} \gamma \delta$ (Basset et al., 2003). Selama infeksi, sistem imun alamiah berperan sebagai pertahanan pertama yang mengenali dan selanjutnya memicu respons proinflamasi terhadap patogen yang menyerang, dimana kemampuannya didasari pada penggunaan aktivasi komplemen, fagositosis, autofagi, dan aktivasi imun oleh berbagai jenis pattern recognition receptors (PRRs) (Medzhitov and Janeway, 2000, Usmar et al., 2017).

Inisiasi respons imun alamiah diawali dengan pengenalan pathogenassociated molecular patterns (PAMPs) oleh PRRs (Usmar et al., 2017). PAMP merupakan pola molekuler vital, yang tidak mengalami perubahan signifikan selama evolusi, yang ada atau diproduksi oleh patogen dan termasuk lipopolisakarida (LPS), lipoprotein, peptidoglikan, lipoarabinomannan dan oligosakarida (Basset et al., 2003) dan dapat dikenali oleh toll-like receptor (TLR), jenis PRR yang paling banyak diteliti, atau jenis PRRs lainnya pada inang, seperti reseptor scavenger, reseptor peptida formil, reseptor manosa dan glycan, reseptor komplemen $\mathrm{CR}_{3}$, beberapa reseptor terlarut seperti CD14, dan PRR sitosol seperti gen I (RIG-I) yang diinduksi asam retinoid (RLRs), dan reseptor nucleotide-binding oligomerization domain (NOD)-like (NLRs) (Murphy and Weaver, 2016, Usmar et al., 2017). PRR ditemukan pada sel epitel, makrofag-monosit, granulosit, sel mast dan sel dendritik (Basset et al., 2003). Untuk review singkat mengenai komponen TLR, RLR, dan sensor asam nukleat lainnya, dapat dilihat pada artikel berikut (Usmar et al., 2017).

Selain dari komponen seluler yang telah disebutkan sebelumnya, sistem imun alamiah juga terdiri dari protein antivirus 
seperti interferon (IFN) $\alpha / \beta$, yang paling lama diketahui dan paling banyak dipelajari, yang bekerja dengan mengikat reseptor IFN tipe I dan menghasilkan transkripsi lebih dari 100 gen yang distimulasi IFN (Ivashkiv and Donlin, 2014, López de Padilla and Niewold, 2016, Murphy and Weaver, 2016). Aktivasi TLR3 , 4, 7, 8, dan 9 akan memicu produksi Interferon (IFN) tipe I yang merupakan pemain kunci dalam memulai dan mengatur respons imun (López de Padilla and Niewold, 2016). IFN tipe I bersifat protektif pada infeksi virus akut namun pada infeksi bakteri dan penyakit autoimun, IFN tipe I dapat berperan protektif atau bahkan merusak (Trinchieri, 2010).

IFN tipe I juga mengaktifkan sel natural killer (NK) dan menginduksi sitokin lain seperti interleukin (IL)-12 yang meningkatkan respons sel NK (López de Padilla and Niewold, 2016). Sel NK adalah sel sitolitik yang membunuh dengan mekanisme antigen-independent. Beberapa jenis virus, seperti herpesvirus, menurunkan produksi kompleks histokompatibilitas mayor (Major Histocompatibility Complex, MHC) dalam sel yang terinfeksi agar terhindar dari pengawasan sistem imun (Orr et al., 2005). Sel NK akan membunuh sel yang tidak mengekspresikan MHC kelas I atau yang mengekspresikannya hanya dalam jumlah yang sedikit (Lodoen and Lanier,
2006, Murphy and Weaver, 2016). Sel yang terinfeksi oleh virus mengirimkan sinyal positif, yaitu indikasi adanya ekspresi molekul MHC yang rendah, sehingga menjadi target sitolisis oleh sel NK. Adapun sel yang tidak terinfeksi biasanya dilindungi dari sitolisis sel NK karena mereka mengirimkan sinyal negatif seperti ekspresi molekul MHC yang tinggi (Campbell and Colonna, 2001). Sel NK mengekspresikan dua tipe reseptor di permukaannya untuk menjaga sel NK tetap berada dalam keadaan respon yang tepat, yaitu tipe reseptor yang akan berinteraksi dengan molekul MHC kelas I di permukaan sel target dan menghambat pembunuhan oleh sel NK (Kumar, 2018), serta tipe reseptor yang berinteraksi dengan molekul di permukaan sel yang mengaktifkan fungsi sitotoksiknya sehingga merangsang sel NK untuk membunuh sel target jika sel NK tidak cukup dihambat oleh interaksinya dengan molekul kelas I (Kumar, 2018).

Selain IFN $\alpha / \beta$, beberapa protein inang lainnya berfungsi dalam pertahanan antivirus. Beberapa sitokin dan kemokin yang diinduksi oleh infeksi virus juga berperan dalam pertahanan. Ini termasuk sitokin TNF- $\alpha$, IFN-g, IL-12, IL-6, dan kemokin seperti MIP-1a. Secara khusus, IL-12 adalah penginduksi kuat IFN-g dari sel NK (Murphy and Weaver, 2016). Kemokin inflamasi juga dapat memainkan peran penting dalam pertahanan antivirus 
bawaan dengan mengatur respons makrofag, neutrofil, DC, dan NK di tempat infeksi (Murphy and Weaver, 2016). Pensinyalan TLR juga mengarah pada pematangan sel dendritik, pemain kunci dalam sistem kekebalan adaptif. Sel dendritik yang teraktivasi akan bermigrasi ke kelenjar getah bening untuk menyajikan antigen ke sel $\mathrm{T}$ sehingga mengaktifkan sel $\mathrm{T}$ tersebut (Hemmi and Akira, 2005).

Inisiasi respons imun adaptif sangat bergantung pada respons imun alamiah yang mengaktifkan sel penyaji antigen (antigen presenting cells, APC), biasanya makrofag atau sel dendritik. APC akan dikirim ke dalam jaringan limfoid oleh sinyal kemokin dan sitokin dan mengaktivasi limfosit (Cantrell, 2015). Beberapa virus dapat menghambat pematangan sel dendritik sehingga mengganggu fungsi APC, seperti herpes simplex virus (HSV) dan virus campak (Griffin, 2010, Kruse et al., 2000).

Dua komponen terpenting dari sistem imun adaptif adalah produksi limfosit $\mathrm{T}$ sitotoksik (cytotoxic $T$ lymphocyte, CTL) yang disebut imunitas seluler dan produksi antibodi yang disekresikan oleh sel B yang disebut imunitas humoral (Aoshi et al., 2011). Komponen lain adalah sel T-helper (Sel $\mathrm{TH}$ ), yang penting dalam regulasi kedua respons ini (Aoshi et al., 2011). Antibodi dan CTL bertindak secara komplementer yaitu antibodi bekerja di lingkungan ekstraseluler untuk mengurangi infektivitas virus dengan mengikat partikel virus bebas sehingga mengurangi jumlah sel yang terinfeksi. Adapun limfosit $\mathrm{T}$ bekerja secara intraseluler untuk mengenali dan membunuh sel yang terinfeksi sebelum pematangan virus terjadi sehingga meminimalkan pelepasan virus yang akan menulari lebih banyak sel inang prospektif (Murphy and Weaver, 2016). Antibodi dapat berfungsi paling efektif untuk mencegah infeksi ulang, terutama pada permukaan mukosa, yang juga memiliki relevansi dengan infeksi HIV (Murphy and Weaver, 2016, Wilen et al., 2012).

Aktivasi limfosit $\mathrm{T}$ diperlukan sebagai inisiasi respons imun adaptif baik dalam bentuk imunitas seluler maupun imunitas humoral. Limfosit $\mathrm{T}$ mengekspresikan reseptor di permukaannya yang mampu mengenali antigen peptida spesifik yang disajikan oleh APC dalam konteks molekul MHC kelas I atau II (Murphy and Weaver, 2016). Reseptor limfosit $T$ berinteraksi dengan antigen peptida dan juga molekul MHC. Dua molekul reseptor limfosit $\mathrm{T}$ yang dikenal adalah cluster of differentiation 4 (CD4) dan CD8. Limfosit $\mathrm{T}$ dewasa hanya memiliki salah satu dari kedua reseptor tersebut dimana sel-T CD8+ mengenali antigen peptida yang disajikan oleh MHC kelas I dan sel-T 
CD4+ mengenali antigen peptida yang disajikan oleh MHC kelas II (Murphy and Weaver, 2016).

Mayoritas sel T CD8+ merupakan prekursor CTL, namun sebagian kecil sel $\mathrm{T}$ CD4+ ditemukan juga dapat berproliferasi menjadi CTL (Murphy and Weaver, 2016). Antigen yang disajikan oleh MHC kelas I berasal dari protein intraseluler dan mewakili semua protein yang disintesis di dalam sel. APC juga dapat menyajikan antigen yang mereka peroleh dari lingkungan eksternal, dalam konteks MHC kelas I, melalui proses yang dikenal sebagai cross-priming (Murphy and Weaver, 2016). Pada cross-priming, antigen virus berasal dari sel terinfeksi yang mati dan difagositosis oleh APC (Nainu et al., 2017). Jika limfosit $\mathrm{T}$ yang berpatroli memiliki reseptor yang mengikat secara khusus ke antigen yang disajikan oleh MHC kelas I, sel T dapat menjadi aktif dan berdiferensiasi menjadi efektor (CTL). Stimulasi lebih lanjut oleh sitokin seperti interleukin-2 (IL-2) dibutuhkan untuk proliferasi CTL. Sumber IL-2 biasanya merupakan sel Thelper yang sebagian besar adalah sel $\mathrm{T}$ CD4+ (Murphy and Weaver, 2016). Sel TH-1 yang teraktivasi mengeluarkan IL-2 serta tumor necrosis factor $\beta$ (TNF- $\beta$ ), interferon $\gamma$ (IFN- $\gamma)$, dan sitokin lainnya. CTL yang teraktivasi akan membunuh sel yang menampilkan epitop yang mereka kenali (Murphy and Weaver, 2016). Dalam upaya menanggulangi infeksi virus, proses eliminasi sel-sel yang terinfeksi virus oleh CTL bergantung pada kemampuan sel dari sebagian besar organ untuk beregenerasi dari sel progenitor (Murphy and Weaver, 2016). Salah satu alasan yang mungkin untuk menjelaskan mengapa MHC kelas I diekspresikan sangat sedikit di sel saraf adalah ketidakmampuan sel saraf untuk beregenerasi apabila terbunuh oleh CTL (Neumann et al., 2002).

Mayoritas limfosit $\mathrm{T} \quad \mathrm{CD} 4+$ merupakan prekursor, namun sebagian kecil sel T CD8+ ditemukan juga dapat menjadi CTL sel $\mathrm{T}$ helper (Luckheeram et al., 2012). Antigen yang disajikan oleh molekul MHC kelas II berasal dari protein ekstraseluler, dan dengan demikian molekul MHC ini mengambil sampel lingkungan ekstraseluler (Murphy and Weaver, 2016). Interaksi reseptor limfosit $\mathrm{T}$ dengan antigen yang disajikan oleh MHC kelas II mengaktivasi Sel TH yang kemudian berproliferasi untuk mengeluarkan sitokin yang penting untuk menimbulkan respons imun seperti yang telah dijelaskan sebelumnya (Murphy and Weaver, 2016). Dua tipe utama sel TH telah dikenali yaitu sel TH-1 dan sel TH-2 yang mengeluarkan sitokin yang saling berlawanan dan memiliki fungsi yang berbeda dalam sistem imun adaptif. Sel TH-1 sangat efektif untuk aktivasi dan fungsi CTL dalam jalur imun seluler dan terutama memproduksi IFN- $\gamma$, LT $\alpha$, TNF- 
a, dan IL-2 untuk membantu mengatur respons inflamasi (Romagnani, 1992). Sedangkan, sel TH-2 optimal untuk aktivasi sel B dan berfungsi di jalur imun humoral serta menghasilkan serangkaian sitokin yang dapat menurunkan fungsi perlindungan sel TH-1, seperti IL-4, IL-5, dan dua sitokin anti inflamasi, IL-10 dan transforming growth factor- $\beta$ (TGF- $\beta$ ) (Romagnani, 1992).

Selain CTL dan sel-TH, salah satu limfosit yang berperan penting dalam sistem imun adaptif adalah limfosit B yang bertanggungjawab untuk memproduksi immunoglobulin atau antibodi (Murphy and Weaver, 2016). Molekul antibodi diproduksi pertama kali sebagai protein integral membran yang akan diekspresikan di permukaan limfosit B dan akan mengaktivasi limfosit B jika terikat dengan antigen. Antigen yang dikenali dapat berupa virus utuh, protein, atau bahkan antigen nonprotein seperti karbohidrat yang dapat diinternalisasi oleh sel B dan terdegradasi oleh jalur pemrosesan antigen MHC kelas II (Murphy and Weaver, 2016). Setelah menerima sinyal kedua dari sel TH-2, sel B akan berproliferasi dan memulai reaksi germinal center (GC) untuk membentuk sel yang memproduksi antibodi (Romagnani, 1992). Secara biologis, perlekatan antibodi pada virus akan memicu lisis virus yang dapat terjadi melalui jalur yang dimediasi komplemen atau oleh jalur sel NK yang disebut sitotoksisitas seluler (antibody-dependent cellular cytotoxicity, ADCC) yang dimediasi oleh sel pembawa reseptor Fc (Gómez Román et al., 2014). Namun, terkadang pengikatan antara reseptor Fc dengan virus yang terikat antibodi dapat memfasilitasi infeksi dan mengakibatkan kerusakan jaringan yang lebih parah, hal ini dapat terjadi pada demam berdarah dan beberapa kasus infeksi HIV (Forthal and Finzi, 2018).

Setelah virus berhasil dieliminasi, sebagian besar CTL dan limfosit lainnya akan menjalani apoptosis sebab sinyal sitokin dan antigen tidak lagi ada. Hal ini menjadi penting sebab proses apoptosis limfosit dan sel sistem adaptif lainnya akan menurunkan respons autoimun yang mungkin terjadi (Murphy and Weaver, 2016, Neumann et al., 2002). Setelah fase ini, sel-sel yang tersisa berdiferensiasi menjadi sel-sel memori, yang tetap menjadi populasi yang kurang lebih stabil dalam inang selama bertahun-tahun dan mewakili kumpulan prekursor limfosit efektor yang dapat diaktifkan setelah pertemuan sekunder dengan antigen, dan memberikan perlindungan saat terjadi infeksi ulang oleh virus yang sama (Murphy and Weaver, 2016). Memori imunologis adalah ciri utama dari imunitas adaptif. Tujuan dari vaksinasi adalah untuk menginduksi memori imunologis yang berumur panjang untuk 
melindungi dari infeksi ulang (Murphy and Weaver, 2016).

\section{Imunoterapi dalam penanganan penyakit terkait infeksi virus}

Secara umum, tujuan dari intervensi farmakologis pada penyakit terkait infeksi virus adalah untuk mengeliminasi patogen penyebab infeksi dan memodulasi respons imun dalam rangka menurunkan efek negatif pasca infeksi. Secara umum, pendekatan melalui imunoterapi menawarkan solusi terapetik dengan cara meningkatkan reaksi pertahanan yang memadai dan bermanfaat saat infeksi sedang berlangsung dan mengatur regulasi aktivasi sistem imun, termasuk inflamasi, untuk menghindari kerusakan jaringan yang tidak perlu pasca infeksi (Khan, 2016, Rouse and Sehrawat, 2010). Pada akhirnya, keseimbangan (homeostasis) respon imun yang terganggu dapat dikembalikan.

\section{Pengembangan obat-obatan} sebagai agen dalam terapi antivirus difokuskan pada penemuan obat yang memiliki kelebihan dalam selektivitas dan efektivitas, stabilitas secara in vivo, dan toksisitas yang lebih rendah. Saat ini, terapi antivirus meliputi penggunaan obat-obatan terhadap infeksi herpesvirus dan virus varicella-zoster, cytomegalovirus, retrovirus (HIV), virus hepatitis B dan C, dan virus influenza (De Clercq and Li, 2016, Razonable, 2011).

Asiklovir masih menjadi terapi standar untuk infeksi virus herpes simpleks (herpes simplex virus, HSV) dan virus varicella (Katzung, 2017). Efikasi valasiklovir, prodrug asiklovir, dan famciclovir, prodrug penciclovir, dalam pengobatan herpes genitalis dan herpes zoster akut telah didokumentasikan dengan baik dalam uji klinis (Tyring et al., 2000). Brivudin dan sorivudine yang merupakan senyawa paling aktif melawan virus varicella-zoster (varicella zoster virus, VZV) dalam kultur sel juga telah berhasil dalam pengobatan herpes zoster (Wutzler, 1997). Saat ini ada beberapa obat antivirus yang dilisensikan untuk pengobatan infeksi cytomegalovirus (CMV) yaitu gansiklovir (GCV), valgansiklovir (VGCV), foscarnet (FOS), dan cidofovir (CDV). Peran agen-agen ini telah berkembang dari pengobatan penyakit menjadi pencegahan infeksi dan penyakit $\mathrm{CMV}$, terutama pada penerima transplantasi organ padat (SOT) dan transplantasi sel induk hematopoietik (HSCT) (Ahmed, 2011, Katzung, 2017).

Untuk menangani infeksi retrovirus, enam kelas senyawa antiretroviral saat ini telah tersedia untuk digunakan yaitu kelas obat non-nucleoside analog reverse transcriptase inhibitors (NNRTIs) seperti delavirdine, efavirenz, nevirapine, dan etravirine; kelas obat 
nucleoside/nucleotide analog reverse transcriptase inhibitors (NRTIs/NtRTIs) seperti abacavir, didanosine, emtricitabine, lamivudine, stavudine, tenofovir, zalcitabine, dan zidovudine; kelas obat integrase inhibitors (INIs) seperti raltegravir; kelas obat protease inhibitors (PIs) seperti atazanavir, darunavir, fosamprenavir, indinavir, lopinavir, litonavir, saquinavir, dan tipranavir; kelas obat antagonis reseptor CCR5 seperti vicriviroc dan pro140; dan kelas obat entry inhibitors (EIs) seperti enfuvirtide dan maraviroc (De Clercq and Li, 2016, Pau and George, 2014).

Lebih lanjut, tujuh obat telah disetujui untuk pengobatan infeksi virus hepatitis B (hepatitis B virus, HBV) kronis di Amerika Serikat: lima analog nukleosida/nukleotida oral yaitu lamivudine, adefovir dipivoxil, tenofovir, entecavir, dan telbivudine serta dua obat interferon injeksi yaitu interferon alfa-2b dan pegylated interferon alfa-2a (Katzung, 2017). Adapun untuk infeksi virus hepatitis $\mathrm{C}$ (hepatitis C virus, $\mathrm{HCV}$ ), standar pengobatan saat ini adalah interferon alfa terpegilasi yang diberikan sekali seminggu yang dikombinasikan dengan ribavirin oral setiap hari. Monoterapi dengan interferon alfa pegilasi direkomendasikan hanya pada pasien yang tidak dapat mentolerir ribavirin sebab terapi kombinasi dengan ribavirin oral lebih efektif daripada monoterapi dengan interferon atau ribavirin saja (Katzung, 2017).

Terkait penanganan infeksi virus influenza, saat ini beberapa obat antivirus telah digunakan. Kelas antivirus influenza yang pertama dikenal adalah penghambat saluran ion M2 seperti amantadine dan rimantadine (Katzung, 2017). Namun, senyawa ini biasanya hanya efektif melawan virus influenza A dan dapat menyebabkan efek samping yang merugikan (De Clercq and $\mathrm{Li}, 2016$, Nicholson et al., 2003). Adapun kelas antivirus influenza yang saat ini banyak digunakan adalah penghambat neuraminidase (NAI) seperti oseltamivir, zanamivir, laninamivir, dan peramivir (Farrukee and Hurt, 2017). Penghambat neuraminidase bekerja dengan cara menghambat aktivitas enzim neuraminidase yang dibutuhkan oleh virus influenza untuk keluar dari sel yang terinfeksi. Penggunaan kelas obat ini telah terbukti efektif secara klinis dalam menangani infeksi virus influenza (De Clercq and Li, 2016, Farrukee and Hurt, 2017). Beberapa antivirus yang telah digunakan secara klinis dan beberapa kandidat antivirus dapat dilihat pada Tabel 1. 
Tabel 1. Daftar antivirus yang telah tersedia di pasaran maupun kandidat antivirus beserta protein target

\begin{tabular}{|c|c|c|c|c|}
\hline Virus & Protein target & $\begin{array}{l}\text { Nama obat (paten) } \\
\text { yang telah tersedia }\end{array}$ & $\begin{array}{l}\text { Kandidat antiviral } \\
\text { baru (novel } \\
\text { inhibitor) }\end{array}$ & Referensi \\
\hline \multirow[t]{2}{*}{$\begin{array}{l}\text { Virus herpes } \\
\text { simplex (HSV) }\end{array}$} & $\begin{array}{l}\text { DNA } \\
\text { polymerase } \\
\text { UL30 }\end{array}$ & $\begin{array}{l}\text { Aciclovir (generik, } \\
\text { Zovirax), brivudine } \\
\text { (zostex), Famciclovir } \\
\text { (Famvir), foscarnet } \\
\text { (Foscavir), idoxuridine } \\
\text { (Dendrid), penciclovir } \\
\text { trifluridine (Denavir), } \\
\text { valaciclovir (Valtrex) }\end{array}$ & $\begin{array}{l}\text { Synguanol, } \\
\text { filociclovir, MBX- } \\
2168, \\
\text { mitoxantrone } \\
\text { dihydrochloride, } \\
\text { PHA76749 }\end{array}$ & $\begin{array}{l}\text { (Li et al., } \\
\text { 2021a) }\end{array}$ \\
\hline & $\begin{array}{l}\text { Protein } \\
\text { selubung }\end{array}$ & Docosanol (Abreva) & NGI-1, C1 & $\begin{array}{l}\text { (Li et al., } \\
\text { 2021a) }\end{array}$ \\
\hline \multirow[t]{2}{*}{$\begin{array}{l}\text { Human } \\
\text { cytomegalovirus } \\
\text { (HCMV) }\end{array}$} & $\begin{array}{l}\text { DNA } \\
\text { polymerase } \\
\text { UL54 }\end{array}$ & $\begin{array}{l}\text { Cidofovir (Vistide), } \\
\text { fomivirsen (Vitravene), } \\
\text { foscarnet (Foscavir), } \\
\text { ganciclovir (Cytovene), } \\
\text { valganciclovir (Valvite) }\end{array}$ & Filociclovir & $\begin{array}{l}\text { (Li et al., } \\
\text { 2021a) }\end{array}$ \\
\hline & Terminase UL56 & Letermovir (Prevymis) & & $\begin{array}{l}\text { (Li et al., } \\
\text { 2021a) }\end{array}$ \\
\hline $\begin{array}{l}\text { Varicella-zoster } \\
\text { virus (VZV) }\end{array}$ & $\begin{array}{l}\text { DNA } \\
\text { polymerase }\end{array}$ & $\begin{array}{l}\text { Aciclovir (generik, } \\
\text { Zovirax), brivudine } \\
\text { (zostex), famciclovir } \\
\text { (Famvir), valaciclovir } \\
\text { (Valtrex), vidarabine } \\
\text { (vira-A) }\end{array}$ & & $\begin{array}{l}\text { (Li et al., } \\
\text { 2021a) }\end{array}$ \\
\hline Human smallpox & $\begin{array}{l}\text { VP37 envelope } \\
\text { wrapping protein }\end{array}$ & Tecovirimat (Tpoxx) & & $\begin{array}{l}\text { (Li et al., } \\
\text { 2021a) }\end{array}$ \\
\hline \multirow[t]{2}{*}{$\begin{array}{l}\text { Hepatitis B virus } \\
\text { (HBV) }\end{array}$} & $\begin{array}{l}\text { DNA } \\
\text { polymerase }\end{array}$ & $\begin{array}{l}\text { Adefovir (Hepsera), } \\
\text { besifovirb, clevudine, } \\
\text { entecavir (Baraclude), } \\
\text { telbivudine (Tyzeka), } \\
\text { tenofovir alafenamide, } \\
\text { tenofovir (Viread) }\end{array}$ & Tenofovir exalidex & $\begin{array}{l}\text { (Li et al., } \\
\text { 2021a) }\end{array}$ \\
\hline & & $\begin{array}{l}\text { Pegylated interferon alfa } \\
\text { 2a (Referon A) Interferon } \\
\text { alfa } 2 \mathrm{~b} \text { (Intron A) }\end{array}$ & & $\begin{array}{l}\text { (Katzung, } \\
2017 \text { ) }\end{array}$ \\
\hline $\begin{array}{l}\text { Hepatitis C virus } \\
(\mathrm{HCV})\end{array}$ & $\begin{array}{l}\text { NS3/4A } \\
\text { protease }\end{array}$ & $\begin{array}{l}\text { Danoprevir (Ganovo), } \\
\text { glecaprevir (Mavyret), } \\
\text { grazoprevir (Zepatier), } \\
\text { paritaprevir (Viekira pak), } \\
\text { simeprevir (Olysio) }\end{array}$ & $\begin{array}{l}\text { Asunaprevir, } \\
\text { faldaprevir } \\
\text { furaprevir, } \\
\text { narlaprevir, } \\
\text { Seraprevir, }\end{array}$ & $\begin{array}{l}\text { (Li et al., } \\
2021 \mathrm{a})\end{array}$ \\
\hline
\end{tabular}




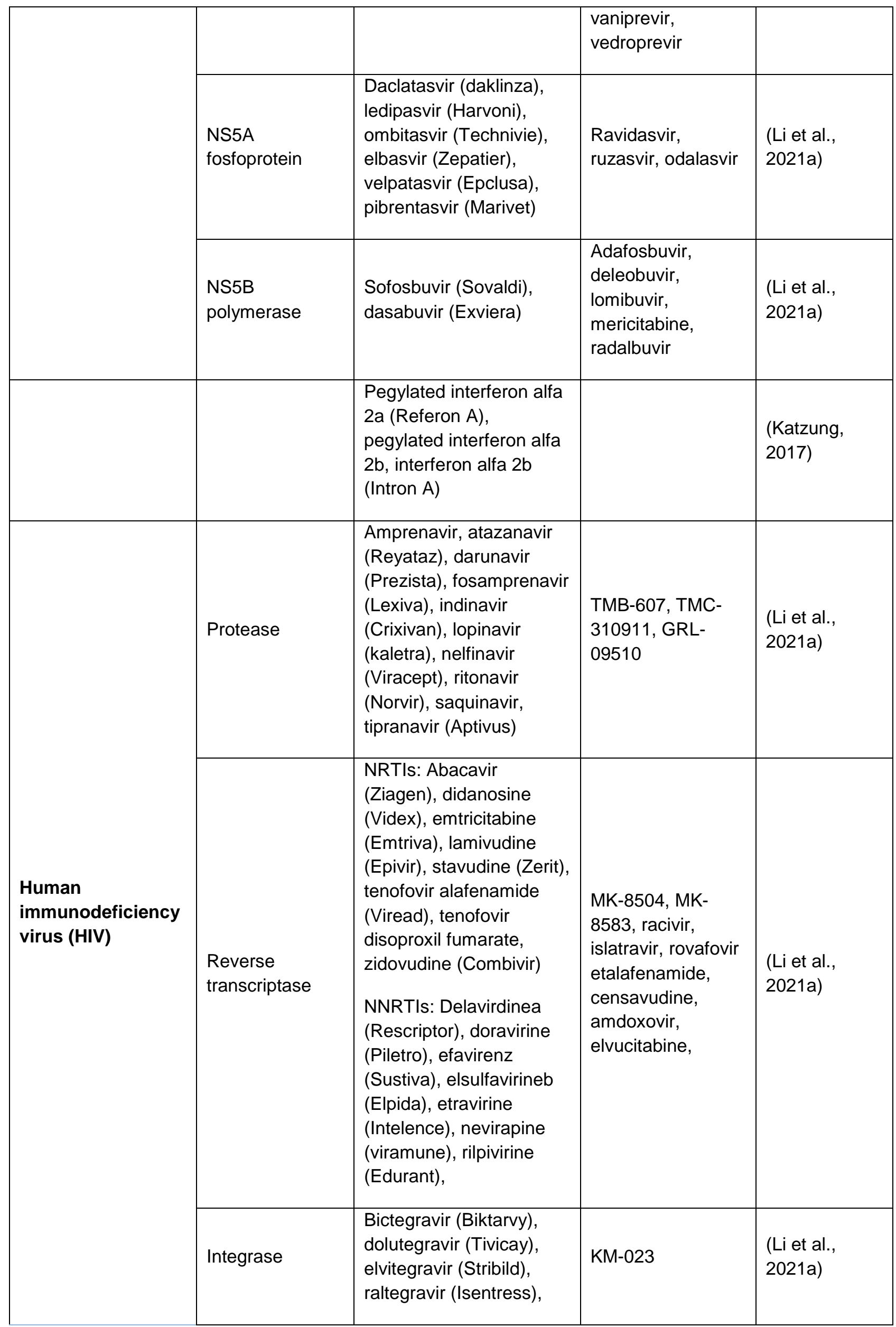




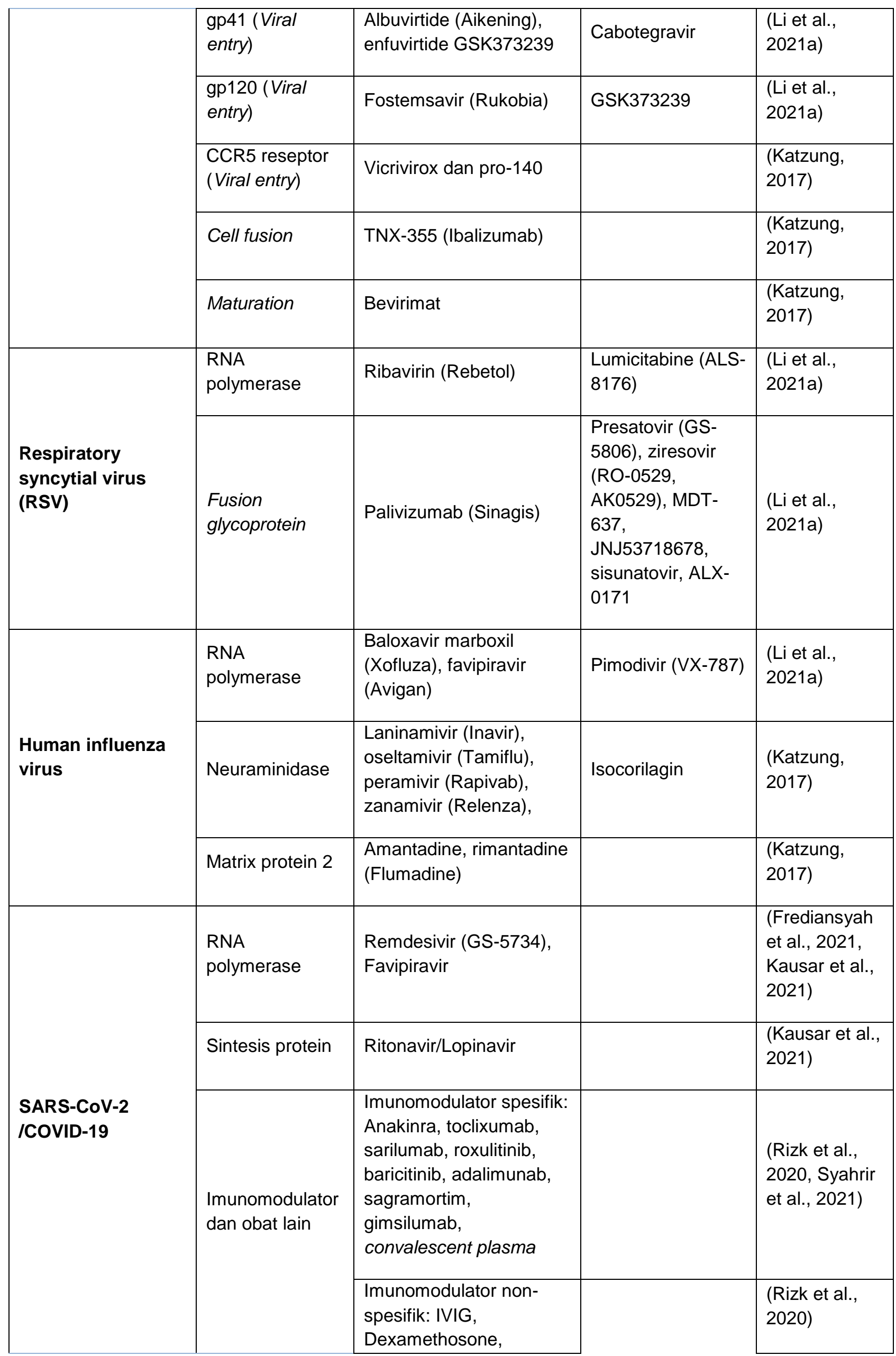

Usmar Dkk., Jurnal Mandala Pharmacon Indonesia 7(1);2021 : 83-111 


\begin{tabular}{|l|l|l|l|}
\hline & $\begin{array}{l}\text { methylprednisolon, } \\
\text { interferon } \beta \text {-1b, } \\
\text { interferona-2b, }\end{array}$ & \\
\cline { 1 - 2 } & $\begin{array}{l}\text { Lain-lain; ACEi/ARB, } \\
\text { azytromycin, } \\
\text { hydroxycloroquin, } \\
\text { cholchicine, } \\
\text { nitazoxanide, ivermectin }\end{array}$ & $\begin{array}{l}\text { (Mudatsir et } \\
\text { al., 2020, Rizk } \\
\text { et al., 2020) }\end{array}$ \\
\hline
\end{tabular}

Riset-riset

pengembangan

\section{imunoterapi}

Antibodi monoklonal (mAb) merupakan salah satu agen yang semakin banyak dipertimbangkan untuk penanganan penyakit yang disebabkan oleh infeksi virus. Pada dasarnya, mAb sejauh ini telah digunakan secara luas untuk menekan transmisi atau perbanyakan virus secara langsung berdasarkan aktivitas penetralan dan/atau pembunuhan sel virus yang dimilikinya (Dibo et al., 2019). Terapi $\mathrm{mAb}$ adalah bentuk imunoterapi pasif yaitu pemberian antibodi eksogen untuk menekan infeksi virus dengan tindakan penargetan langsung dan cepat. Pendekatan terapeutik ini berbeda dengan pendekatan vaksin, yang bertujuan untuk menstimulasi respon imun endogen dari inang sehingga terbentuk imunitas yang berkelanjutan (Pelegrin et al., 2015). Namun, dalam beberapa tahun terakhir, beberapa penelitian telah mengungkapkan bahwa terapi $\mathrm{mAb}$ dapat digunakan untuk merekrut sistem kekebalan endogen dari organisme yang terinfeksi dan menginduksi efek seperti vaksin (Pelegrin et al., 2015).

Respons imun antivirus yang diinduksi, atau diperkuat, oleh imunoterapi berbasis $\mathrm{mAb}$ telah diamati pada berbagai virus yang menyerang manusia melalui pendekatan pre-klinis menggunakan primata dalam model infeksi HIV yang menggunakan mAb generasi kedua (Bossart et al., 2011, Geisbert et al., 2014). Adapun penggunaan antibodi monoklonal dalam terapi coronavirus disease (COVID)-19 masih terus diinvestigasi. Namun hasil yang menjanjikan telah dilaporkan untuk penggunaan klinis kombinasi terapi antibodi monoklonal bamlanivimab dan etesevimab dalam pengobatan COVID-19 ringan hingga sedang (Gottlieb et al., 2021). Bamlanivimab dan etesevimab adalah antibodi monoklonal terhadap protein spike SARS-CoV-2, virus penyebab COVID-19, yang dirancang untuk memblokir perlekatan virus dan penetrasinya ke dalam sel manusia (Gottlieb et al., 2021). Beberapa antibodi monoklonal yang digunakan dalam 
mengatasi infeksi virus dapat dilihat pada Tabel 2.

Selain melalui pendekatan antibodi monoklonal, saat ini juga telah dilakukan beberapa pendekatan farmasetik termasuk di antaranya adalah dari segi bentuk sediaan dan juga mode penghantaran obat ke daerah infeksi (Chakravarty and Vora, 2021). Salah satu pendekatan bentuk sediaan adalah melalui bentuk nanopartikel yang memiliki banyak keuntungan serta telah diterapkan secara luas dalam berbagai bidang. Teknik nanoteknologi telah digunakan dalam sistem penghantaran obat karena mampu membawa zat ke dalam tubuh, meningkatkan kemanjuran terapeutik dan mengurangi toksisitas zat yang dibawa (Chakravarty and Vora, 2021, Delshadi et al., 2021, Li et al., 2021b). Partikel nano diprediksi bekerja secara langsung pada virus atau menyebabkan perubahan struktural pada virus, sehingga mencegahnya menembus sel target. Beberapa penelitian menyelidiki aktivitas antivirus nanopartikel serta beberapa diantaranya menunjukkan aksi intraseluler nanopartikel melalui interferensi protein (Cagno et al., 2018, Jamali et al., 2018, Sabet et al., 2017).

Pendekatan berbasis nanoteknologi baru-baru ini disarankan dalam terapi infeksi SARS-CoV-2 (Bhavana et al., 2020, Hassanzadeh, 2020, Weiss et al., 2020). Hasil studi yang berhasil pada virus yang menginfeksi daerah pernapasan dapat diterapkan pada virus SARS-CoV-2 melalui polimer nanopartikel anorganik yang menggunakan protein berbasis peptida (Sivasankarapillai et al., 2020). Antivirus yang disiapkan dalam bentuk nanopartikel menunjukkan peningkatan efektivitas dan mengatasi keterbatasan seperti ketersediaan hayati yang rendah, efek samping yang merugikan, frekuensi konsumsi, dan waktu pengobatan (Singh et al., 2017). Namun, penelitian yang menyelidiki interaksi antara partikel nano dengan sistem imun dibutuhkan untuk pengembangan sistem nanocarrier yang biokompatibel, biodegradable, dan non-sitotoksik untuk bertindak secara khusus pada infeksi virus tanpa mempengaruhi sel dan jaringan yang sehat.

Imunoterapi untuk mengatasi infeksi virus juga dapat menggunakan pendekatan berbasis clustered regularly interspaced short palindromic repeats (CRISPR). Metode ini merupakan salah satu teknik yang sedang hangat dibicarakan di dunia medis. Teknik CRISPR-Cas9 memungkinkan pengeditan DNA oleh endonuklease Cas9, dipandu oleh urutan RNA yang mampu berpasangan dengan urutan basa target. Teknik ini telah digunakan dengan cepat, mudah, dan efisien untuk memodifikasi gen endogen dan 
manipulasi genom berbagai jenis sel yang penting secara klinis (Cong et al., 2013, Jinek et al., 2012, Sander and Joung, 2014). Beberapa virus dengan genom DNA dapat bertahan dalam sel inang dalam bentuk episom seperti HSV dan HBV (Hensel et al., 2018, Nicoll et al., 2012, Serquiña and Ziegelbauer, 2017) atau berintegrasi ke dalam kromosom inang, seperti dalam kasus HPV (Arias-Pulido et al., 2006). Intervensi replikasi genom virus melalui penggunaan sistem CRISPR-Cas dapat mengontrol infeksi berikutnya (Chen et al., 2018). Aktivitas antivirus dari sistem berbasis CRISPR-Cas telah dibuktikan secara in vivo pada pasien leukemia yang tidak memiliki viral load HIV-1 yang terdeteksi setelah menerima sumsum tulang dengan mutasi homozigot delta tipe 5 CC pada reseptor kemokin 32 (CCR5 432$)$ (Allers et al., 2011). Contoh pertama penggunaan CRISPR-Cas dalam mekanisme pertahanan terhadap infeksi virus secara in vitro dan in vivo dipublikasikan tidak lama setelah metode tersebut diperkenalkan (Lin et al., 2014), yang melaporkan penurunan signifikan dalam ekspresi protein virus HBV. Beberapa penelitian telah menunjukkan bahwa pengeditan DNA oleh sistem CRISPR-Cas mampu mengeliminasi HBV dalam kultur sel (Seeger and Sohn, 2014).
Sejumlah strategi in vitro dan in vivo sedang dirancang untuk mencegah infeksi, termasuk oleh SARS-CoV-2, dengan bantuan teknik CRISPR-Cas (Ding et al., 2021, Strich and Chertow, 2019). Beberapa pendekatan yang mungkin dilakukan dengan memanfaatkan sistem CRISPR-Cas diantaranya adalah memodifikasi reseptor yang digunakan oleh virus untuk masuk ke dalam sel sehingga pada akhirnya akan mencegah pengikatan reseptor virus dan mencegah replikasi dari virus; menghambat ekspresi beberapa gen yang menyandikan protein yang penting bagi replikasi virus (dengan metode knock-down atau bahkan knock out), sehingga mencegah replikasi virus dan membuat virus lebih rentan terhadap respons imun inang; meningkatkan ekspresi penghambat transkripsi inang sehingga menghalangi replikasi dan/atau menyebabkan penurunan transkripsi RNA virus dan jumlah virion; dan mengeksisi gen virus yang mengintegrasikan DNA-nya ke dalam genom inang (Chen et al., 2018, de Buhr and Lebbink, 2018, De Silva Feelixge et al., 2018, Ding et al., 2021, Koujah et al., 2019, Lee, 2019, Sanchesda-Silva et al., 2019, Strich and Chertow, 2019).

Manipulasi langsung genom virus menggunakan sistem CRISPR-Cas juga memiliki potensi yang besar dalam 
pencegahan infeksi virus kronis maupun patogen lainnya. Namun, kesulitannya cukup besar dan implikasi terhadap manfaat klinis belum dapat diketahui. Meskipun banyak tantangan yang perlu diselesaikan, potensi pencegahan infeksi dan penyembuhan pasien melalui pemanfaatan teknologi CRISPR telah

Tabel 2. Beberapa contoh vaksin dan antibodi monoklonal untuk pencegahan dan terapi penyakit terkait infeksi virus

\begin{tabular}{|c|c|c|c|}
\hline Virus & $\begin{array}{c}\text { Contoh sediaan yang } \\
\text { tersedia }\end{array}$ & Keterangan & Referensi \\
\hline HCMV & $\begin{array}{l}\text { Antibodi monoklonal } \\
\text { CSJ148 (LJP538 and } \\
\text { LJP539) Novartis }\end{array}$ & $\begin{array}{l}\text { CSJ148 adalah kombinasi dari dua mAbs } \\
\text { manusia anti-HCMV yang mengikat dan } \\
\text { menghambat fungsi virus HCMV gB (LJP538) } \\
\text { dan pentameric gHkompleks (LJP539). Kedua } \\
\text { antibodi diisolasi dari sel B yang dimortalisasi } \\
\text { (akibat infeksi EBV). }\end{array}$ & $\begin{array}{l}\text { (Macagno et al., } \\
\text { 2010) }\end{array}$ \\
\hline HIV & $\begin{array}{l}\text { Antibodi monoklonal } \\
\text { Ibalizumab (TNX-355), } \\
\text { Genentech }\end{array}$ & $\begin{array}{l}\text { Antibodi monoklonal Ibalizumab berikatan } \\
\text { dengan CD4 manusia, yang merupakan } \\
\text { reseptor utama pada HIV-1. }\end{array}$ & $\begin{array}{l}\text { (Song et al., } \\
\text { 2010) }\end{array}$ \\
\hline RSV & $\begin{array}{l}\text { Antibodi monoklonal } \\
\text { Palivizumab (Synagis; } \\
\text { MEDI-493, Medlmmune) }\end{array}$ & $\begin{array}{l}\text { Disetujui untuk profilaksis pada bayi dengan } \\
\text { risiko tinggi RSV, Synagis adalah a-mAb } \\
\text { manusia dari isoform IgG1yang menargetkan } \\
\text { glikoprotein F RSV. }\end{array}$ & $\begin{array}{l}\text { (Luna et al., } \\
\text { 2020, McLellan } \\
\text { et al., 2010) }\end{array}$ \\
\hline Ebola & $\begin{array}{l}\text { Antibodi monoklonal } \\
\text { ZMapp, National Institute } \\
\text { of Allergy and Infectious } \\
\text { Diseases (NIAID) }\end{array}$ & $\begin{array}{l}\text { ZMapp adalah kombinasi tiga antibodi yang } \\
\text { dioptimalkan (terdiri dari murine mAbs } \mathrm{m} 1 \mathrm{H} 3 \text {, } \\
\text { m2G4 dan } \mathrm{m} 4 \mathrm{G} 7 \text { ). }\end{array}$ & $\begin{array}{l}\text { (Qiu et al., } \\
\text { 2014) }\end{array}$ \\
\hline Rabies & $\begin{array}{l}\text { Antibodi monoklonal } \\
\text { CL184 (CR57 and } \\
\text { CR4098), Crucell }\end{array}$ & $\begin{array}{l}\text { CL184 adalah gabungan mAb yang terdiri dari } \\
\text { CR57 dan CR4098, dan CL184 adalah hasil } \\
\text { evaluasi sebagai pengganti human rabies } \\
\text { immunoglobulin (HRIG) (NCT00708084, } \\
\text { NCT00656097, NCT0122838). }\end{array}$ & $\begin{array}{l}\text { (Bakker et al., } \\
\text { 2008) }\end{array}$ \\
\hline Influenza & $\begin{array}{l}\text { Antibodi monoklonal } \\
\text { VIS410, Visterra, Inc }\end{array}$ & $\begin{array}{l}\text { VIS410 menargetkan epitop yang } \\
\text { dikonservasi di stem influenza A } \\
\text { hemagglutinin (HA). Hasil rekayasa } \\
\text { menggunakan informasi struktural pada } \\
\text { antarmuka antibodi-antigen. VIS410 sedang } \\
\text { dalam uji klinis Fase } 2 \text { (NCT02989194). }\end{array}$ & $\begin{array}{l}\text { (Hershberger et } \\
\text { al., 2019) }\end{array}$ \\
\hline
\end{tabular}




\begin{tabular}{|l|l|l|l|}
\hline SARS- & $\begin{array}{l}\text { Antibodi monoklonal } \\
\text { CR6261, Crucell Holland } \\
\text { BV and the National } \\
\text { Institute of Allergy and } \\
\text { Infectious Diseases } \\
\text { (NIAID) }\end{array}$ & $\begin{array}{l}\text { Diisolasi dari individu sehat yang divaksinasi } \\
\text { menggunakan metode seleksi tampilan phage } \\
\text { pada rekombinan H5 HA. }\end{array}$ & $\begin{array}{l}\text { (Ekiert et al., } \\
\text { 2009) }\end{array}$ \\
\hline \multirow{3}{*}{$\begin{array}{l}\text { SARS- } \\
\text { CoV-2 }\end{array}$} & $\begin{array}{l}\text { Antibody monoklonal } \\
\text { Bamlanivimab (LY-coV55 } \\
\text { and LY3819253) }\end{array}$ & $\begin{array}{l}\text { Antibodi monoklonal yang secara khusus } \\
\text { ditujukan untuk melawan lonjakan protein } \\
\text { SARS-CoV-2, dirancang untuk memblokir } \\
\text { perlekatan virus dan masuk ke dalam sel } \\
\text { manusia. Bamlanivimab dan etesevimab } \\
\text { mengikat situs yang berbeda tetapi } \\
\text { overlapping pada protein virus. }\end{array}$ & $\begin{array}{l}\text { (Taylor et al., } \\
\text { 2021) }\end{array}$ \\
\cline { 2 - 5 } & $\begin{array}{l}\text { Antibody monoklonal } \\
\text { Etesevimab (LY-CoV016 } \\
\text { and LY3832479) }\end{array}$ & \\
\hline
\end{tabular}

\section{KESIMPULAN}

Imunoterapi merupakan bidang yang berkembang melalui interaksi bidang imunologi, farmakologi dan farmakoterapi yang memiliki perkembangan yang pesat terutama dalam kondisi pandemi COVID-19 yang dihadapi saat ini. Meskipun terapi dan obat-obatan yang digunakan dalam bidang imunofarmakologi masih terbatas serta banyak hal yang belum dapat ditemukan, namun teknologi baru dan kemajuan pesat dalam pengetahuan tentang regulasi sistem imun telah menjadikan imunoterapi sebagai bidang yang memiliki potensi besar dan menjanjikan dalam penanganan infeksi virus maupun patogen lain. Oleh karena itu, konsep imunoterapi serta relevansinya dengan penyakit manusia merupakan salah satu solusi yang menawarkan pilihan baru untuk kebutuhan medis yang belum terpenuhi terkait penyakit infeksi akibat virus.

\section{UCAPAN TERIMA KASIH}

Terima kasih kami ucapkan kepada anggota UNHAS Fly Research Group (UFRG) yang telah banyak membantu dalam diskusi terkait materi yang ditulis dalam artikel ini. Gambar 1 dalam artikel ini dibuat menggunakan aplikasi Biorender (Biorender.com).

\section{DAFTAR PUSTAKA}

Ahmed, A. 2011. Antiviral treatment of cytomegalovirus infection. Infect Disord Drug Targets, 11, 475-503.

Allers, K., Hütter, G., Hofmann, J., Loddenkemper, C., Rieger, K., Thiel, E. \& Schneider, T. 2011. Evidence for the cure of HIV infection by CCR $5 \Delta 32 / \Delta 32$ stem cell transplantation. Blood, 117 , 2791-9.

Aoshi, T., Koyama, S., Kobiyama, K., Akira, S. \& Ishii, K. J. 2011. Innate and adaptive immune responses to viral infection and vaccination. Current Opinion in Virology, 1, 226-232.

Arias-Pulido, H., Peyton, C. L., Joste, N. E., Vargas, H. \& Wheeler, C. M. 2006. Human papillomavirus type 16 integration in cervical carcinoma in situ and in invasive cervical cancer. $\mathrm{J}$ Clin Microbiol, 44, 1755-62.

Bakker, A. B., Python, C., Kissling, C. J., 
Pandya, P., Marissen, W. E., Brink, M. F., Lagerwerf, F., Worst, S., Van Corven, E., Kostense, S., Hartmann, K., Weverling, G. J., Uytdehaag, F., Herzog, C., Briggs, D. J., Rupprecht, C. E., Grimaldi, R. \& Goudsmit, J. 2008. First administration to humans of a monoclonal antibody cocktail against rabies virus: safety, tolerability, and neutralizing activity. Vaccine, 26, 5922-7.

Basset, C., Holton, J., O'mahony, R. \& Roitt, I. 2003. Innate immunity and pathogen-host interaction. Vaccine, 21 Suppl 2, S12-23.

Bhat, S. A., Sarwar, Z., Gillani, S. Q., Un Nisa, M., Reshi, I., Nabi, N., Xie, S., Fazili, K. M., Roberts, T. M. \& Andrabi, S. 2020. Polyomavirus Small T Antigen Induces Apoptosis in Mammalian Cells through the UNC5B Pathway in a PP2ADependent Manner. J Virol, 94.

Bhavana, V., Thakor, P., Singh, S. B. \& Mehra, N. K. 2020. COVID-19: Pathophysiology, treatment options, nanotechnology approaches, and research agenda to combating the SARS-CoV2 pandemic. Life Sci, 261, 118336.

Bossart, K. N., Geisbert, T. W., Feldmann, H., Zhu, Z., Feldmann, F., Geisbert, J. B., Yan, L., Feng, Y. R., Brining, D., Scott, D., Wang, Y., Dimitrov, A. S., Callison, J., Chan, Y. P., Hickey, A. C., Dimitrov, D. S., Broder, C. C. \& Rockx, B. 2011. A neutralizing human monoclonal antibody protects african green monkeys from hendra virus challenge. Sci Transl Med, 3, 105 ra103.

Braithwaite, A. W. \& Russell, I. A. 2001. Induction of cell death by adenoviruses. Apoptosis, 6, 359-70.

Cagno, V., Andreozzi, P., D'alicarnasso, M., Jacob Silva, P., Mueller, M., Galloux, M., Le Goffic, R., Jones, S. T., Vallino, M., Hodek, J., Weber, J., Sen, S., Janeček, E.R., Bekdemir, A., Sanavio, B., Martinelli, C., Donalisio, M., Rameix Welti, M.-A., Eleouet, J.-F., Han, Y., Kaiser, L., Vukovic, L., Tapparel, C., Král, P., Krol, S., Lembo, D. \& Stellacci, F. 2018. Broad-spectrum non-toxic antiviral nanoparticles with a virucidal inhibition mechanism. Nature Materials, 17, 195203.

Campbell, K. S. \& Colonna, M. 2001. Human natural killer cell receptors and signal transduction. Int Rev Immunol, 20, 33370.

Cantrell, D. 2015. Signaling in lymphocyte activation. Cold Spring Harbor perspectives in biology, 7, a018788.

Chakravarty, M. \& Vora, A. 2021. Nanotechnology-based antiviral therapeutics. Drug Deliv Transl Res, 11, 748-787.

Chen, S., Yu, X. \& Guo, D. 2018. CRISPRCas Targeting of Host Genes as an Antiviral Strategy. Viruses, 10.

Cong, L., Ran, F. A., Cox, D., Lin, S., Barretto, R., Habib, N., Hsu, P. D., Wu, X., Jiang, W., Marraffini, L. A. \& Zhang, F. 2013. Multiplex genome engineering using CRISPR/Cas systems. Science, 339, 81923.

De Buhr, H. \& Lebbink, R. J. 2018. Harnessing CRISPR to combat human viral infections. Curr Opin Immunol, 54, 123129.

De Clercq, E. \& Li, G. 2016. Approved Antiviral Drugs over the Past 50 Years. Clin Microbiol Rev, 29, 695-747.

De Silva Feelixge, H. S., Stone, D., Roychoudhury, P., Aubert, M. \& Jerome, K. R. 2018. CRISPR/Cas9 and Genome Editing for Viral Disease-Is Resistance Futile? ACS Infect Dis, 4, 871-880.

Deeks, S. G., Overbaugh, J., Phillips, A. \& Buchbinder, S. 2015. HIV infection. Nature Reviews Disease Primers, 1, 15035.

Delshadi, R., Bahrami, A., Mcclements, D. J., Moore, M. D. \& Williams, L. 2021. Development of nanoparticle-delivery systems for antiviral agents: A review. J Control Release, 331, 30-44.

Dibo, M., Battocchio, E. C., Dos Santos Souza, L. M., Da Silva, M. D. V., Banin-Hirata, B. K., Sapla, M. M. M., Marinello, P., Rocha, S. P. D. \& Faccin-Galhardi, L. C. 2019. Antibody Therapy for the Control of Viral Diseases: An Update. Curr Pharm Biotechnol, 20, 1108-1121.

Dimitrov, D. S. 2004. Virus entry: molecular mechanisms and biomedical applications. Nature Reviews Microbiology, 2, 109122.

Ding, R., Long, J., Yuan, M., Jin, Y., Yang, H., Chen, M., Chen, S. \& Duan, G. 2021. 
CRISPR/Cas System: A Potential Technology for the Prevention and Control of COVID-19 and Emerging Infectious Diseases. Frontiers in Cellular and Infection Microbiology, 11.

Ekiert, D. C., Bhabha, G., Elsliger, M. A., Friesen, R. H., Jongeneelen, M., Throsby, M., Goudsmit, J. \& Wilson, I. A. 2009. Antibody recognition of a highly conserved influenza virus epitope. Science, 324, 246-51.

Farrukee, R. \& Hurt, A. C. 2017. Antiviral Drugs for the Treatment and Prevention of Influenza. Current Treatment Options in Infectious Diseases, 9, 318-332.

Fields, B. N., Knipe, D. M. \& Howley, P. M. 2013. Fields Virology, Wolters Kluwer Health.

Forthal, D. N. \& Finzi, A. 2018. Antibodydependent cellular cytotoxicity in HIV infection. AIDS (London, England), 32, 2439-2451.

Frediansyah, A., Nainu, F., Dhama, K., Mudatsir, M. \& Harapan, H. 2021. Remdesivir and its antiviral activity against COVID-19: A systematic review. Clinical Epidemiology and Global Health, 9, 123-127.

Geisbert, T. W., Mire, C. E., Geisbert, J. B., Chan, Y. P., Agans, K. N., Feldmann, F., Fenton, K. A., Zhu, Z., Dimitrov, D. S., Scott, D. P., Bossart, K. N., Feldmann, H. \& Broder, C. C. 2014. Therapeutic treatment of Nipah virus infection in nonhuman primates with a neutralizing human monoclonal antibody. Sci Transl Med, 6, 242 ra82.

Gómez Román, V. R., Murray, J. C. \& Weiner, L. M. 2014. Chapter 1 - AntibodyDependent Cellular Cytotoxicity (ADCC). In: ACKERMAN, M. E. \& NIMMERJAHN, F. (eds.) Antibody Fc. Boston: Academic Press.

Gorbalenya, A. E., Krupovic, M., Mushegian, A., Kropinski, A. M., Siddell, S. G., Varsani, A., Adams, M. J., Davison, A. J., Dutilh, B. E., Harrach, B., Harrison, R. L., Junglen, S., King, A. M. Q., Knowles, N. J., Lefkowitz, E. J., Nibert, M. L., Rubino, L., Sabanadzovic, S., Sanfaçon, H., Simmonds, P., Walker, P. J., Zerbini, F. M. \& Kuhn, J. H. 2020. The new scope of virus taxonomy: partitioning the virosphere into 15 hierarchical ranks. Nat Microbiol, 5, 668-674.

Gottlieb, R. L., Nirula, A., Chen, P., Boscia, J., Heller, B., Morris, J., Huhn, G., Cardona, J., Mocherla, B., Stosor, V., Shawa, I., Kumar, P., Adams, A. C., Van Naarden, J., Custer, K. L., Durante, M., Oakley, G., Schade, A. E., Holzer, T. R., Ebert, P. J., Higgs, R. E., Kallewaard, N. L., Sabo, J., Patel, D. R., Klekotka, P., Shen, L. \& Skovronsky, D. M. 2021. Effect of Bamlanivimab as Monotherapy or in Combination With Etesevimab on Viral Load in Patients With Mild to Moderate COVID-19: A Randomized Clinical Trial. JAMA, 325, 632-644.

Graham, B. S. \& Sullivan, N. J. 2018. Emerging viral diseases from a vaccinology perspective: preparing for the next pandemic. Nat Immunol, 19, 2028.

Griffin, D. E. 2010. Measles virus-induced suppression of immune responses. Immunol Rev, 236, 176-89.

Grove, J. \& Marsh, M. 2011. The cell biology of receptor-mediated virus entry. The Journal of cell biology, 195, 1071-1082.

Harapan, H., Itoh, N., Yufika, A., Winardi, W., Keam, S., Te, H., Megawati, D., Hayati, Z., Wagner, A. L. \& Mudatsir, M. 2020. Coronavirus disease 2019 (COVID-19): A literature review. Journal of Infection and Public Health, 13, 667-673.

Harding, S. D., Faccenda, E., Southan, C., Maffia, P. \& Davies, J. A. 2018. A new guide to immunopharmacology. Nature Reviews Immunology, 18, 729-729.

Hassanzadeh, P. 2020. Nanotheranostics against COVID-19: From multivalent to immune-targeted materials. J Control Release, 328, 112-126.

Helenius, A. 2018. Virus Entry: Looking Back and Moving Forward. J Mol Biol, 430, 1853-1862.

Hemmi, H. \& Akira, S. 2005. TLR signalling and the function of dendritic cells. Chem Immunol Allergy, 86, 120-135.

Hensel, K. O., Cantner, F., Bangert, F., Wirth, S. \& Postberg, J. 2018. Episomal HBV persistence within transcribed host nuclear chromatin compartments involves HBx. Epigenetics Chromatin, 11,34 . 
Hershberger, E., Sloan, S., Narayan, K., Hay, C. A., Smith, P., Engler, F., Jeeninga, R., Smits, S., Trevejo, J., Shriver, Z. \& Oldach, D. 2019. Safety and efficacy of monoclonal antibody VIS410 in adults with uncomplicated influenza A infection: Results from a randomized, double-blind, phase-2, placebo-controlled study. EBioMedicine, 40, 574-582.

Hoeben, R. C. \& Uil, T. G. 2013. Adenovirus DNA replication. Cold Spring Harbor perspectives in biology, 5, a013003a013003.

Ivashkiv, L. B. \& Donlin, L. T. 2014. Regulation of type I interferon responses. Nat Rev Immunol, 14, 36-49.

Jamali, A., Mottaghitalab, F., Abdoli, A., Dinarvand, M., Esmailie, A., Kheiri, M. T. \& Atyabi, F. 2018. Inhibiting influenza virus replication and inducing protection against lethal influenza virus challenge through chitosan nanoparticles loaded by siRNA. Drug Deliv Transl Res, 8, 12-20.

Jinek, M., Chylinski, K., Fonfara, I., Hauer, M., Doudna, J. A. \& Charpentier, E. 2012. A Programmable Dual-RNA-Guided DNA Endonuclease in Adaptive Bacterial Immunity. Science, 337, 816-821.

Kates, J. R. \& Mcauslan, B. R. 1967. Poxvirus DNA-dependent RNA polymerase. Proceedings of the National Academy of Sciences of the United States of America, 58, 134-141.

Katzung, B. G. 2017. Basic and Clinical Pharmacology 14th Edition, McGrawHill Education.

Kausar, S., Said Khan, F., Ishaq Mujeeb Ur Rehman, M., Akram, M., Riaz, M., Rasool, G., Hamid Khan, A., Saleem, I., Shamim, S. \& Malik, A. 2021. A review: Mechanism of action of antiviral drugs. International Journal of Immunopathology and Pharmacology, 35, 20587384211002621.

Khan, M. M. 2016. Immunopharmacology, Springer International Publishing.

Koujah, L., Shukla, D. \& Naqvi, A. R. 2019. CRISPR-Cas based targeting of host and viral genes as an antiviral strategy. Semin Cell Dev Biol, 96, 53-64.

Kruse, M., Rosorius, O., Krätzer, F., Stelz, G., Kuhnt, C., Schuler, G., Hauber, J. \& Steinkasserer, A. 2000. Mature dendritic cells infected with herpes simplex virus type 1 exhibit inhibited T-cell stimulatory capacity. Journal of virology, 74, 71277136.

Kumar, S. 2018. Natural killer cell cytotoxicity and its regulation by inhibitory receptors. Immunology, 154, 383-393.

Lee, C. 2019. CRISPR/Cas9-Based Antiviral Strategy: Current Status and the Potential Challenge. Molecules (Basel, Switzerland), 24, 1349.

Li, C., Wang, J. C.-Y., Taylor, M. W. \& Zlotnick, A. 2012. In vitro assembly of an empty picornavirus capsid follows a dodecahedral path. Journal of virology, 86, 13062-13069.

Li, G., Jing, X. \& Zhang, P. 2021a. Antiviral Classification. In: BAMFORD, D. H. \& ZUCKERMAN, M. (eds.) Encyclopedia of Virology. 4th ed.: Elsevier.

Li, Y., Xiao, Y., Chen, Y. \& Huang, K. 2021b. Nano-based approaches in the development of antiviral agents and vaccines. Life Sci, 265, 118761.

Lin, S. R., Yang, H. C., Kuo, Y. T., Liu, C. J., Yang, T. Y., Sung, K. C., Lin, Y. Y., Wang, H. Y., Wang, C. C., Shen, Y. C., Wu, F. Y., Kao, J. H., Chen, D. S. \& Chen, P. J. 2014. The CRISPR/Cas9 System Facilitates Clearance of the Intrahepatic HBV Templates In Vivo. Mol Ther Nucleic Acids, 3, e186.

Lodoen, M. B. \& Lanier, L. L. 2006. Natural killer cells as an initial defense against pathogens. Curr Opin Immunol, 18, 3918.

López De Padilla, C. M. \& Niewold, T. B. 2016. The type I interferons: Basic concepts and clinical relevance in immune-mediated inflammatory diseases. Gene, 576, 14-21.

Luckheeram, R. V., Zhou, R., Verma, A. D. \& Xia, B. 2012. CD4+ T Cells: Differentiation and Functions. Clinical and Developmental Immunology, 2012, 925135.

Luna, M. S., Manzoni, P., Paes, B., Baraldi, E., Cossey, V., Kugelman, A., Chawla, R., Dotta, A., Rodríguez Fernández, R., Resch, B. \& Carbonell-Estrany, X. 2020. Expert consensus on palivizumab use for respiratory syncytial virus in developed countries. Paediatr Respir Rev, 33, 35-44. 
Macagno, A., Bernasconi, N. L., Vanzetta, F., Dander, E., Sarasini, A., Revello, M. G., Gerna, G., Sallusto, F. \& Lanzavecchia, A. 2010. Isolation of human monoclonal antibodies that potently neutralize human cytomegalovirus infection by targeting different epitopes on the $\mathrm{gH} / \mathrm{gL} / \mathrm{UL} 128$ 131A complex. J Virol, 84, 1005-13.

Maginnis, M. S. 2018. Virus-Receptor Interactions: The Key to Cellular Invasion. J Mol Biol, 430, 2590-2611.

Matrosovich, M., Herrler, G. \& Klenk, H. D. 2015. Sialic Acid Receptors of Viruses. Top Curr Chem, 367, 1-28.

Mcfadden, G. 2005. Poxvirus tropism. Nature Reviews Microbiology, 3, 201-213.

Mclellan, J. S., Chen, M., Kim, A., Yang, Y., Graham, B. S. \& Kwong, P. D. 2010. Structural basis of respiratory syncytial virus neutralization by motavizumab. Nat Struct Mol Biol, 17, 248-50.

Medzhitov, R. \& Janeway, C., Jr. 2000. Innate immunity. N Engl J Med, 343, 338-44.

Mudatsir, M., Yufika, A., Nainu, F., Frediansyah, A., Megawati, D., Pranata, A., Mahdani, W., Ichsan, I., Dhama, K. \& Harapan, H. 2020. Antiviral Activity of Ivermectin Against SARS-CoV-2: An Old-Fashioned Dog with a New TrickA Literature Review. Scientia Pharmaceutica, 88, 36.

Murphy, K. M. \& Weaver, C. 2016. Janeway's Immunobiology, Garland Science, Taylor \& Francis Group, LLC.

Nainu, F., Shiratsuchi, A. \& Nakanishi, Y. 2017. Induction of Apoptosis and Subsequent Phagocytosis of VirusInfected Cells As an Antiviral Mechanism. Frontiers in Immunology, 8.

Neumann, H., Medana, I. M., Bauer, J. \& Lassmann, H. 2002. Cytotoxic T lymphocytes in autoimmune and degenerative CNS diseases. Trends Neurosci, 25, 313-9.

Nicholson, K. G., Wood, J. M. \& Zambon, M. 2003. Influenza. Lancet, 362, 1733-45.

Nicoll, M. P., Proença, J. T. \& Efstathiou, S. 2012. The molecular basis of herpes simplex virus latency. FEMS microbiology reviews, 36, 684-705.

Orr, M. T., Edelmann, K. H., Vieira, J., Corey, L., Raulet, D. H. \& Wilson, C. B. 2005. Inhibition of MHC class I is a virulence factor in herpes simplex virus infection of mice. PLoS pathogens, 1, e7-e7.

Pau, A. K. \& George, J. M. 2014. Antiretroviral therapy: current drugs. Infect Dis Clin North Am, 28, 371-402.

Pelegrin, M., Naranjo-Gomez, M. \& Piechaczyk, M. 2015. Antiviral Monoclonal Antibodies: Can They Be More Than Simple Neutralizing Agents? Trends Microbiol, 23, 653-665.

Qiu, X., Wong, G., Audet, J., Bello, A., Fernando, L., Alimonti, J. B., FaustherBovendo, H., Wei, H., Aviles, J., Hiatt, E., Johnson, A., Morton, J., Swope, K., Bohorov, O., Bohorova, N., Goodman, C., Kim, D., Pauly, M. H., Velasco, J., Pettitt, J., Olinger, G. G., Whaley, K., Xu, B., Strong, J. E., Zeitlin, L. \& Kobinger, G. P. 2014. Reversion of advanced Ebola virus disease in nonhuman primates with ZMapp. Nature, 514, 47-53.

Razonable, R. R. 2011. Antiviral drugs for viruses other than human immunodeficiency virus. Mayo Clin Proc, 86, 1009-26.

Riley, L. W. \& Blanton, R. E. 2018. Advances in Molecular Epidemiology of Infectious Diseases: Definitions, Approaches, and Scope of the Field. Microbiol Spectr, 6.

Rizk, J. G., Kalantar-Zadeh, K., Mehra, M. R., Lavie, C. J., Rizk, Y. \& Forthal, D. N. 2020. Pharmaco-Immunomodulatory Therapy in COVID-19. Drugs, 80, 12671292.

Romagnani, S. 1992. Type 1 T helper and type 2 T helper cells: Functions, regulation and role in protection and disease. International Journal of Clinical and Laboratory Research, 21, 152-158.

Rossmann, M. G., He, Y. \& Kuhn, R. J. 2002. Picornavirus-receptor interactions. Trends Microbiol, 10, 324-31.

Rouse, B. T. \& Sehrawat, S. 2010. Immunity and immunopathology to viruses: what decides the outcome? Nature Reviews Immunology, 10, 514-526.

Ryu, W.-S. 2017. Virus Life Cycle. Molecular Virology of Human Pathogenic Viruses, 31-45.

Sabet, S., George, M. A., El-Shorbagy, H. M., Bassiony, H., Farroh, K. Y., Youssef, T. \& Salaheldin, T. A. 2017. Gelatin nanoparticles enhance delivery of 
hepatitis C virus recombinant NS2 gene. PLoS One, 12, e0181723.

San Martín, C. 2012. Latest insights on adenovirus structure and assembly. Viruses, 4, 847-877.

Sanches-Da-Silva, G. N., Medeiros, L. F. S. \& Lima, F. M. 2019. The Potential Use of the CRISPR-Cas System for HIV-1 Gene Therapy. Int J Genomics, 2019, 8458263.

Sander, J. D. \& Joung, J. K. 2014. CRISPRCas systems for editing, regulating and targeting genomes. Nat Biotechnol, 32, 347-55.

Seeger, C. \& Sohn, J. A. 2014. Targeting Hepatitis B Virus With CRISPR/Cas9. Mol Ther Nucleic Acids, 3, e216.

Serquiña, A. K. \& Ziegelbauer, J. M. 2017. How herpesviruses pass on their genomes. The Journal of cell biology, 216, 2611-2613.

Sharma, A., Li, X., Bangari, D. S. \& Mittal, S. K. 2009. Adenovirus receptors and their implications in gene delivery. Virus Res, 143, 184-94.

Singh, L., Kruger, H. G., Maguire, G. E. M., Govender, T. \& Parboosing, R. 2017. The role of nanotechnology in the treatment of viral infections. Ther Adv Infect Dis, 4, 105-131.

Sivasankarapillai, V. S., Pillai, A. M., Rahdar, A., Sobha, A. P., Das, S. S., Mitropoulos, A. C., Mokarrar, M. H. \& Kyzas, G. Z. 2020. On Facing the SARS-CoV-2 (COVID-19) with Combination of Nanomaterials and Medicine: Possible Strategies and First Challenges. Nanomaterials (Basel), 10.

Song, R., Franco, D., Kao, C.-Y., Yu, F., Huang, Y. \& Ho, D. D. 2010. Epitope mapping of ibalizumab, a humanized anti-CD4 monoclonal antibody with antiHIV-1 activity in infected patients. Journal of virology, 84, 6935-6942.

Strich, J. R. \& Chertow, D. S. 2019. CRISPRCas Biology and Its Application to Infectious Diseases. Journal of clinical microbiology, 57, e01307-18.

Syahrir, S., Ariastiwi, D. A., Manggau, M. A., Nainu, F. \& Bahar, M. A. 2021. Efektivitas Sarilumab Sebagai Kandidat Obat Covid19: Sebuah Kajian Sistematik. Majalah Farmasi dan Farmakologi, 25, 37-41.
Taylor, J. M., Lin, E., Susmarski, N., Yoon, M., Zago, A., Ware, C. F., Pfeffer, K., Miyoshi, J., Takai, Y. \& Spear, P. G. 2007. Alternative entry receptors for herpes simplex virus and their roles in disease. Cell Host Microbe, 2, 19-28.

Taylor, P. C., Adams, A. C., Hufford, M. M., De La Torre, I., Winthrop, K. \& Gottlieb, R. L. 2021. Neutralizing monoclonal antibodies for treatment of COVID-19. Nature Reviews Immunology, 21, 382393.

Trinchieri, G. 2010. Type I interferon: friend or foe? J Exp Med, 207, 2053-63.

Tyring, S. K., Beutner, K. R., Tucker, B. A., Anderson, W. C. \& Crooks, R. J. 2000. Antiviral therapy for herpes zoster: randomized, controlled clinical trial of valacyclovir and famciclovir therapy in immunocompetent patients 50 years and older. Arch Fam Med, 9, 863-9.

Usmar, U., Arfiansyah, R. \& Nainu, F. 2017. Sensor Asam Nukleat Sebagai Aktivator Imunitas Intrinsik Terhadap Patogen Intraseluler. Galenika Journal of Pharmacy, 3, 174-190.

Verhoef, J., Van Kessel, K. \& Snippe, H. 2019. Immune Response in Human Pathology: Infections Caused by Bacteria, Viruses, Fungi, and Parasites. Nijkamp and Parnham's Principles of Immunopharmacology, 165-178.

Wagner, E. K., Hewlett, M. J., Bloom, D. C. \& Camerini, D. 2007. Basic Virology, Wiley.

Weiss, C., Carriere, M., Fusco, L., Capua, I., Regla-Nava, J. A., Pasquali, M., Scott, J. A., Vitale, F., Unal, M. A., Mattevi, C., Bedognetti, D., Merkoçi, A., Tasciotti, E., Yilmazer, A., Gogotsi, Y., Stellacci, F. \& Delogu, L. G. 2020. Toward Nanotechnology-Enabled Approaches against the COVID-19 Pandemic. ACS Nano, 14, 6383-6406.

Weller, S. K. \& Coen, D. M. 2012. Herpes simplex viruses: mechanisms of DNA replication. Cold Spring Harbor perspectives in biology, 4, a013011a013011.

Whitley, R. J. \& Roizman, B. 2001. Herpes simplex virus infections. Lancet, 357, 1513-8.

Wilen, C. B., Tilton, J. C. \& Doms, R. W. 
2012. HIV: cell binding and entry. Cold Spring Harbor perspectives in medicine, 2, a006866.

Wutzler, P. 1997. Antiviral therapy of herpes simplex and varicella-zoster virus infections. Intervirology, 40, 343-56.

Yu, J. C., Khodadadi, H., Malik, A., Davidson, B., Salles, É. D. S. L., Bhatia, J., Hale, V. L. \& Baban, B. 2018. Innate Immunity of Neonates and Infants. Frontiers in Immunology, 9.

Yuen, M.-F., Chen, D.-S., Dusheiko, G. M.,
Janssen, H. L. A., Lau, D. T. Y., Locarnini, S. A., Peters, M. G. \& Lai, C.L. 2018. Hepatitis B virus infection. Nature Reviews Disease Primers, 4, 18035.

Zumla, A., Chan, J. F., Azhar, E. I., Hui, D. S. \& Yuen, K. Y. 2016. Coronaviruses drug discovery and therapeutic options. Nat Rev Drug Discov, 15, 327-47.7

Copyright (c) 2021 Jurnal Mandala Pharmacon Indonesia; This article is an open access article distributed under the terms and conditions of the Creative Commons Attribution License (http://creativecommons.org/licenses/by/4.0/) 